\title{
The Feasibility of Electrochemical Ammonia Synthesis in Molten LiCl-KCl Eutectics
}

\author{
Ian J. McPherson, ${ }^{[a]}$ Tim Sudmeier, ${ }^{[a]}{ }^{2}$ Joshua P. Fellowes, ${ }^{[a]}$ lan Wilkinson, ${ }^{[b]}$ Tim Hughes, ${ }^{[b]}$ S.C. Edman Tsang ${ }^{*}[a]$
}

\begin{abstract}
Molten $\mathrm{LiCl}$ and related eutectic electrolytes are known to permit direct electrochemical reduction of $\mathrm{N}_{2}$ to $\mathrm{N}^{3-}$ with high efficiency. It had been proposed that this could be coupled with $\mathrm{H}_{2}$ oxidation in an electrolytic cell to produce $\mathrm{NH}_{3}$ at ambient pressure. Here, this proposal is tested in a $\mathrm{LiCl}-\mathrm{KCl}-\mathrm{Li}_{3} \mathrm{~N}$ cell and is found not to be the case, as the previous assumption of the direct electrochemical oxidation of $\mathrm{N}^{3-}$ to $\mathrm{NH}_{3}$ is grossly over-simplified. We find that $\mathrm{Li}_{3} \mathrm{~N}$ added to the molten electrolyte promotes the spontaneous and simultaneous chemical disproportionation of $\mathrm{H}_{2}(\mathrm{H}$ oxidation state 0$)$ into $\mathrm{H}^{-}(\mathrm{H}$ oxidation state -1$)$ and $\mathrm{H}^{+}$in form of $\mathrm{NH}^{2-} / \mathrm{NH}_{2} / \mathrm{NH}_{3}(\mathrm{H}$ oxidation state +1 ) in the absence of applied current, resulting in nonFaradaic release of $\mathrm{NH}_{3}$. It is further observed that $\mathrm{NH}^{2-}$ and $\mathrm{NH}_{2}$ possess their own redox chemistry. However, these spontaneous reactions allow us to propose an alternative, truly catalytic cycle. By adding $\mathrm{LiH}$, rather than $\mathrm{Li}_{3} \mathrm{~N}, \mathrm{~N}_{2}$ can be reduced to $\mathrm{N}^{3-}$ while stoichiometric amounts of $\mathrm{H}^{-}$are oxidised to $\mathrm{H}_{2}$. The $\mathrm{H}_{2}$ can then react spontaneously with $\mathrm{N}^{3-}$ to form $\mathrm{NH}_{3}$, regenerating $\mathrm{H}^{-}$and closing the catalytic cycle. Initial tests show a peak $\mathrm{NH}_{3}$ synthesis rate of $2.4 \times 10^{-8}$ $\mathrm{mol} \mathrm{cm} \mathrm{cm}^{-1}$ at a maximum current efficiency of $4.2 \%$. Isotopic labelling with ${ }^{15} \mathrm{~N}_{2}$ confirms the resulting $\mathrm{NH}_{3}$ is from catalytic $\mathrm{N}_{2}$ reduction.
\end{abstract}

\section{Introduction}

Synthetic ammonia plays a central role in modern civilisation, accounting for as much as half of the fixed nitrogen in the terrestrial nitrogen cycle. ${ }^{[1]}$ While production on this huge scale is necessary to meet the food demands of a growing population, it comes with a correspondingly large and increasing energy requirement, consuming over $1 \%$ of the global energy supply. ${ }^{[2,3]}$ Furthermore, since this energy is currently supplied from fossil fuels, there are also significant $\mathrm{CO}_{2}$ emissions from this process, estimated at over $1 \%$ of global $\mathrm{CO}_{2}$ emitted in $2012 .{ }^{[4]} \mathrm{As}$ a result, widespread efforts are underway to decrease the energy consumption of this process while developing new technologies that are compatible with renewable energy resources. Simultaneously, ammonia has begun to gain attention as a green energy vector, particularly for high capacity storage in isolated

[a] Dr I. J. McPherson, Mr T. Sudmeier, Mr J.P. Fellowes, Prof. S.C. E. Tsang

Department of Chemistry

University of Oxford

Inorganic Chemistry Laboratory, South Parks Road, Oxford, OX1

3QR

E-mail: edman.tsang@chem.ox.ac.uk

[b] Dr I Wilkinson, Dr T Hughes

CT NTF

Siemens plc

Wharf Road, Oxford, OX29 4BP

Supporting information for this article is given via a link at the end of the document.((Please delete this text if not appropriate)) locations. With an energy density similar to methanol, zero carbon emission on combustion and widespread storage and distribution already demonstrated by the agricultural sector, it is an attractive candidate. However, the challenge remains the de-carbonisation of its production.

Currently most ammonia is produced using the HaberBosch process, employing high pressures (200 bar) and an Fe catalyst to obtain equilibrium conversion of $\mathrm{N}_{2}$ and $\mathrm{H}_{2}$ into $\mathrm{NH}_{3}{ }^{[5]}$ These complex plants generally operate on a very large scale, running continuously at high pressure and deriving the required $\mathrm{H}_{2}$ from steam reforming of natural gas. However, this model is not easily converted to use renewable energy, whose wider geographic dispersion and inherent intermittency disfavour the use of large, continuous, centralised reactors. In their place a new generation of distributed, small scale, easily switched plants are envisaged whose activity can be ramped up and down to match the renewable energy supply. ${ }^{[6]}$ Holding back this vision are the difficulties in designing small yet efficient and productive reactors. The kinetics of $\mathrm{N}_{2}$ reduction are very slow, requiring the HaberBosch process to operate at high temperatures. Using temperature to increase rate carries a thermodynamic penalty, however, as the equilibrium constant, $K$, decreases significantly from room temperature $(K(300 \mathrm{~K})=766)$ to higher temperatures $\left(K(700 \mathrm{~K})=9.8 \times 10^{-3}\right.$, see calculation in section S2, SI). ${ }^{[5]}$ This is compensated in the Haber-Bosch process with high reactant pressures, which itself has significant financial and energetic costs.

In contrast to thermal reactors, electrochemical cells permit the position of equilibrium to be controlled via the cell potential. If suitable redox reactions can be found, judicious control over potential enables the requirement for high pressures to be relaxed, in addition to the other benefits of electrochemical cells such as being able to control activity directly via applied voltage or current, rather than via parameters such as temperature or pressure which take much longer to change. Several electrochemical cells have been proposed for ammonia synthesis, with those based on molten salt electrolytes reporting the highest rates and current efficiencies ${ }^{[7-12]}$ In particular, it has been reported that molten $\mathrm{LiCl}$, and related eutectics, possess the fascinating ability to stabilise the $\mathrm{N}^{3-}$ ion and establish the reversible $\mathrm{N}_{2} / \mathrm{N}^{3-}$ redox couple at ambient pressure. ${ }^{[13-16]}$ Ito and co-workers proposed that this could be utilised in an ammonia synthesis process, by coupling the reduction of $\mathrm{N}_{2}$ (Eq. 1) at a cathode with its oxidation in the presence of $\mathrm{H}_{2}$ (Eq. 2) at an anode. ${ }^{[10]}$

$$
\begin{aligned}
& \mathrm{N}_{2}+6 \mathrm{e}^{-} \rightarrow 2 \mathrm{~N}^{3-} \\
& 2 \mathrm{~N}^{3-}+3 \mathrm{H}_{2} \rightarrow 2 \mathrm{NH}_{3}+6 \mathrm{e}^{-}
\end{aligned}
$$

They subsequently demonstrated that $\mathrm{NH}_{3}$ was rapidly evolved from cells containing $\mathrm{N}^{3-}$ when $\mathrm{H}_{2}, \mathrm{H}_{2} \mathrm{O}$ and several other $\mathrm{H}$ donors were added and potential was applied. ${ }^{[10,17-20]}$ Mechanistic investigation of the reaction with $\mathrm{H}_{2}$ found that the rate of $\mathrm{NH}_{3}$ evolution was independent of applied potential, but had a first 
order dependence on $\mathrm{H}_{2} \cdot{ }^{[21]}$ However, to date the ability of such cells to catalytically produce $\mathrm{NH}_{3}$ has yet to be carefully confirmed, with only initial rates and non-catalytic conversion of $\mathrm{N}^{3-}$ presented. [22]

\section{Results and Discussion}

\section{Ammonia Synthesis from $\mathrm{Li}_{3} \mathrm{~N}$}

To confirm that the cell described by Ito and co-workers ${ }^{[10]}$ is truly capable of catalytic ammonia synthesis, we reproduced their setup in which $\mathrm{N}_{2}$ and $\mathrm{H}_{2}$ bubbled through $\mathrm{Ni}$ foam electrodes into molten $\mathrm{LiCl}-\mathrm{KCl}$ eutectic containing $\mathrm{Li}_{3} \mathrm{~N}(0.5 \mathrm{~mol} \%)$. A potential of $0.7 \mathrm{~V} \mathrm{vs} \mathrm{Li}^{+} / \mathrm{Li}$ was applied to the $\mathrm{H}_{2} / \mathrm{Ni}$ foam working electrode in a three-electrode setup, with a $\mathrm{Ag} / \mathrm{AgCl}$ electrode as the reference and the $\mathrm{N}_{2} / \mathrm{Ni}$ foam as the counter electrode. The current, evolved $\mathrm{NH}_{3}$ and $\mathrm{N}_{2} / \mathrm{Ni}$ electrode potential were then sampled over the course of 8 hours (Figure 1) before the current became negligible. Over the first hour the rate of ammonia evolution is $3 \times 10^{-9} \mathrm{~mol} \mathrm{~cm}^{-2} \mathrm{~s}^{-1}$, identical to the rate reported previously after 40 minutes. ${ }^{[10]}$ However, after one hour the rate begins to rise dramatically, peaking after 5.5 hours at $1.5 \times 10^{-6}$ mol cm$~^{-2} \mathrm{~s}^{-1}$ before falling. The delay in peak $\mathrm{NH}_{3}$ evolution is suggested to be due to the strong absorption of $\mathrm{NH}_{3}$ by the melt in the presence of $\mathrm{N}^{3-}$, as reported previously and attributed to the reaction of $\mathrm{NH}_{3}$ with $\mathrm{N}^{3-}$ to form $\mathrm{NH}_{2}{ }^{-}$and $\mathrm{NH}^{2-}$ species (Eq. 3). ${ }^{[22]}$

$\mathrm{N}^{3-}+\mathrm{NH}_{3} \rightarrow \mathrm{NH}_{2}^{-}+\mathrm{NH}^{2-}$

Interestingly the current seems to be inversely correlated with the rate, starting high but falling at the start of ammonia evolution, eventually becoming negative after 3.5 hours (Figure 1B, left axis). This behaviour correlates with the $\mathrm{N}_{2}$ electrode potential, which starts off more negative than the $\mathrm{H}_{2}$ electrode (as expected) at $+0.5 \mathrm{~V} \mathrm{vs} \mathrm{Li}^{+} / \mathrm{Li}$ but rises steadily to become more positive than it, reversing the polarity of the cell (Figure 1B, right axis). This reversal suggests that the composition of the electrolyte near the anode is becoming harder to oxidise, possibly a result of the depletion of $\mathrm{N}^{3-}$ and accumulation of $\mathrm{NH}^{2-}$ and $\mathrm{NH}_{2}^{-}$described above.
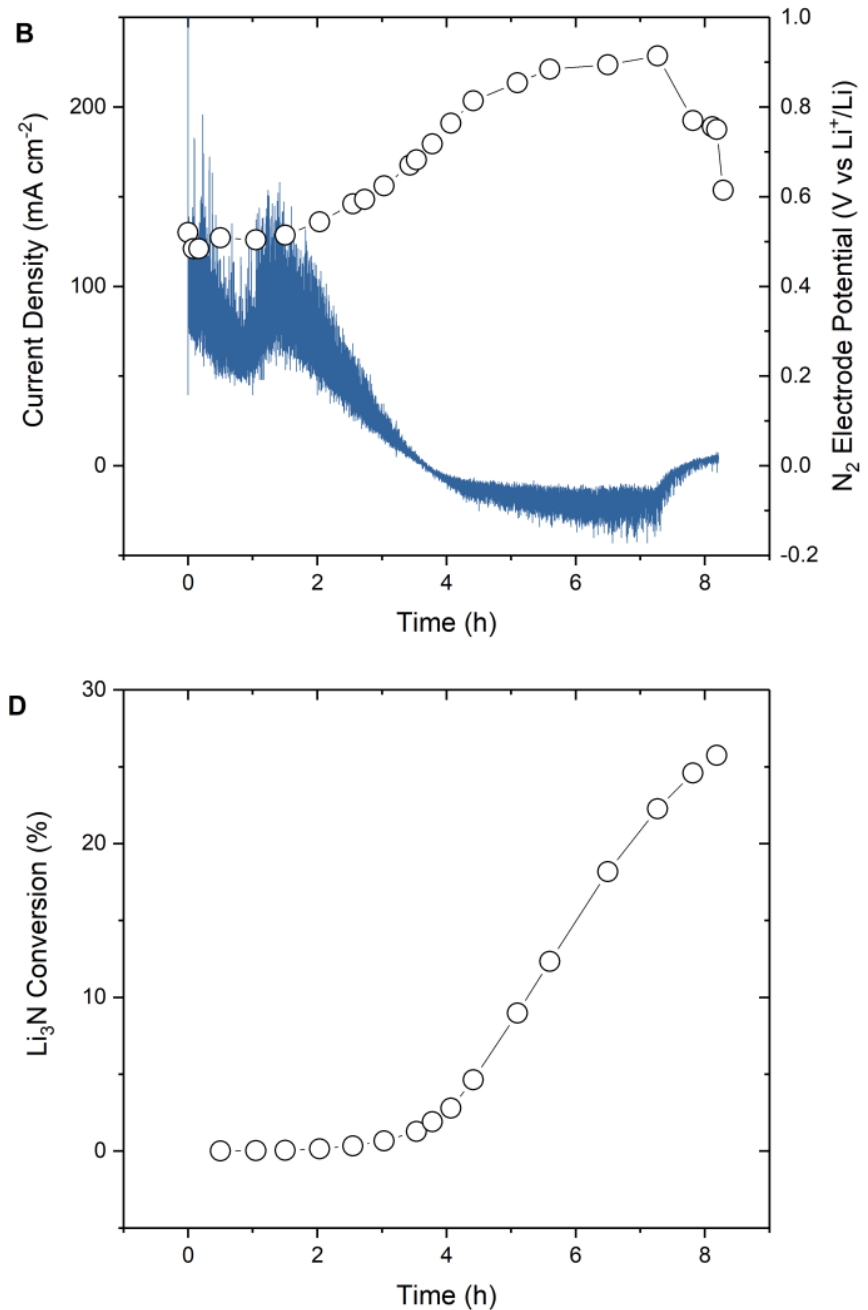
Figure 1. Ammonia evolution under anodic potential control. $\mathrm{H}_{2}$ electrode potential: $+0.7 \mathrm{~V}$ vs $\mathrm{Li}^{+} / \mathrm{Li}$, Electrolyte: $\mathrm{LiCl}-\mathrm{KCl}-\mathrm{Li} 3 \mathrm{~N}(0.5 \mathrm{~mol} \%), 723 \mathrm{~K}$. Ni foam electrodes Flow rates: $\mathrm{H}_{2}$ (working electrode) $5 \mathrm{~mL} \mathrm{~min}^{-1}, \mathrm{~N}_{2}$ (counter electrode) $45 \mathrm{~mL} \mathrm{~min}^{-1}$, Ar (headspace) $350 \mathrm{~mL} \mathrm{~min}^{-1}$. A: Ammonia evolution rate. Inset: 0-3 hours, rate

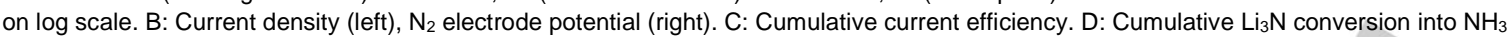

The yield of ammonia $(2.5 \mathrm{mmol})$ was equivalent to conversion of only $25 \mathrm{~mol} \%$ of the initial $\mathrm{Li}_{3} \mathrm{~N}(10 \mathrm{mmol}$, Figure $1 \mathrm{C})$, making it impossible to determine if any $\mathrm{N}_{2}$ reduction occurred at all (only yields greater than $100 \mathrm{~mol} \%$ would unambiguously indicate catalysis). Furthermore, we found that the current efficiency exceeded $100 \%$, i.e. the overall charge passed was insufficient to account for the ammonia produced (Figure 1D), revealing that the primary ammonia evolution process here is not Faradaic as originally attributed. ${ }^{[23]}$ To determine if there is any Faradaic component to ammonia evolution in this system, a control experiment was carried out under open circuit conditions (Figure 2). The initial rates are lower than seen at $0.7 \mathrm{~V} \mathrm{vs} \mathrm{Li}^{+} / \mathrm{Li}$ and there is a longer delay before any increase is observed, however after 4 hours the rate does dramatically increase, reaching a peak rate again at 5.5 hours of $3.6 \times 10^{-6} \mathrm{~mol} \mathrm{~cm}^{-2} \mathrm{~s}^{-1}$ before falling to negligible rates. The final yield is again equivalent to only $30 \%$ conversion of the $\mathrm{Li}_{3} \mathrm{~N}$ initially present. This behaviour is very similar to the case with applied current, although a slower onset is observed, and shows that the ammonia evolved under applied potential is not produced in a Faradaic reaction and is actually the result of a spontaneous chemical reaction between the initial dissolved $\mathrm{Li}_{3} \mathrm{~N}$ and $\mathrm{H}_{2}$ (Eq. 4). This contrasts to the original claim of electrocatalytic $\mathrm{N}_{2}$ reduction for ammonia production under this molten medium. Note that no $\mathrm{NH}_{3}$ was evolved in a separate control experiment where current was applied to the $\mathrm{LiCl} / \mathrm{KCl} / \mathrm{Li}_{3} \mathrm{~N}$ electrolyte without supplying $\mathrm{H}_{2}$, confirming that $\mathrm{N}^{3-}$ is reacting with $\mathrm{H}_{2}$ and not residual water.

$\mathrm{N}^{3-}+3 \mathrm{H}_{2} \rightarrow \mathrm{NH}_{3}+3 \mathrm{H}^{-}$

The spontaneous chemical reaction is actually very similar to the desired electrochemical oxidation reaction (Eq. 2), except the electrons from $\mathrm{N}^{3-}$ are used to reduce $\mathrm{H}_{2}$ to $\mathrm{H}^{-}$, rather than being transferred to the electrode. This reaction is spontaneous in the solid state (as the Li salts), although only slightly $\left(\Delta_{\mathrm{r}} G=\right.$ $\left.1.15 \mathrm{~kJ} \mathrm{~mol}^{-1}\right),{ }^{[24]}$ and has been explored extensively for its role in $\mathrm{H}_{2}$ storage, via the reversible formation of $\mathrm{Li}_{2} \mathrm{NH}$ and $\mathrm{LiNH}_{2}{ }^{[25]}$ It is therefore proposed that the reaction occurs stepwise here too, via the formation of $\mathrm{NH}^{2-}$ and $\mathrm{NH}_{2}{ }^{-}$species (Eq. 4a-c), and/or via the bimolecular decomposition of $\mathrm{NH}_{2}^{-}$(Eq. 5).

$\mathrm{N}^{3-}+\mathrm{H}_{2} \rightarrow \mathrm{NH}^{2-}+\mathrm{H}^{-}$
$\mathrm{NH}^{2-}+\mathrm{H}_{2} \rightarrow \mathrm{NH}_{2}^{-}+\mathrm{H}^{-}$
$\mathrm{NH}_{2}^{-}+\mathrm{H}_{2} \rightarrow \mathrm{NH}_{3}+\mathrm{H}^{-}$
$2 \mathrm{NH}_{2}^{-} \rightarrow \mathrm{NH}^{2-}+\mathrm{NH}_{3}$

Evidence that these reactions occur in the molten state is provided by two direct observations: first, the significant $\mathrm{H}_{2}$ partial pressure dependence of the open circuit potential; and secondly, the appearance of IR peaks in the $\mathrm{N}-\mathrm{H}$ stretching region following hydrogenation. Figure $3 \mathrm{C}$ shows the open circuit potential of a $\mathrm{LiCl}-\mathrm{KCl}-\mathrm{Li}_{3} \mathrm{~N}(0.5 \mathrm{~mol} \%)$ melt, measured at a Ni wire, recorded as a function of $P\left(\mathrm{H}_{2}\right)$ both just after $\mathrm{H}_{2}$ was introduced, and after $20 \%$ conversion of the $\mathrm{Li}_{3} \mathrm{~N}$ to $\mathrm{NH}_{3}$ by $\mathrm{H}_{2}$ bubbling. There is a strong positive correlation between $P\left(\mathrm{H}_{2}\right)$ and the potential, indicating not only that $\mathrm{H}_{2}$ is involved in a potential determining equilibrium, but that it is the oxidised partner. This is consistent with the potential determining equilibrium being that between $\mathrm{H}_{2}$ and $\mathrm{H}^{-}$(Eq. 6), giving rise to Nernst equation (Eq. 7), where $E^{\circ}$ is the formal potential of the $\mathrm{H}_{2} / \mathrm{H}^{-}$couple, $P\left(\mathrm{H}_{2}\right)$ is the partial pressure of $\mathrm{H}_{2}$ and $X\left(\mathrm{H}^{-}\right)$the mole fraction of $\mathrm{H}^{-}$

$$
\begin{aligned}
& \mathrm{H}_{2}+2 \mathrm{e}=2 \mathrm{H}^{-} \\
& E=E^{0^{\prime}}\left(\mathrm{H}_{2} / \mathrm{H}^{-}\right)+(R T / 2 F) \ln P\left(\mathrm{H}_{2}\right) / \mathrm{X}\left(\mathrm{H}^{-}\right)^{2}
\end{aligned}
$$

This is further supported by the translation of the curve towards more negative potentials as the reactions proceeds, consistent with an increase in $\mathrm{H}^{-}$mole fraction. Evaluation of the slope in terms of Eq. 7 suggests the number of electrons, $n=2.5$ close to the expected value of 2 . Additional evidence for Eq. $4 \mathrm{a}-\mathrm{c}$ is provided by IR spectroscopy of the melt frozen midway through reaction, where peaks are observed in the region expected for both $\mathrm{LiNH}_{2}$ and $\mathrm{Li}_{2} \mathrm{NH}$ (Figure 3D). ${ }^{[26]}$ This is also supported by recent in situ infrared experiments in which $\mathrm{N}-\mathrm{H}$ stretches were observed when $\mathrm{H}_{2}$ was bubbled through $\mathrm{Li}_{3} \mathrm{~N}$. ${ }^{[27]}$

The stepwise change in equilibrium potential of the $\mathrm{H}_{2}$ electrode observed during the open circuit control measurement, and its change in polarity during the constant potential $0.7 \mathrm{~V}$ experiment, further suggest that the intermediates formed are themselves redox active. The redox properties of all proposed components of the electrolyte were therefore characterized to understand their interactions and determine if a truly catalytic path to ammonia synthesis in this system is indeed possible.

\section{Voltammetric Analysis of Redox Active Species}

The reactions of the proposed $\mathrm{NH}$ species were characterized using cyclic voltammetry, which provides characteristic potentials for the onset of redox reactions as well as insight into the reaction kinetics. In $\mathrm{LiCl}-\mathrm{KCl}-\mathrm{Li}_{3} \mathrm{~N}(0.5 \mathrm{~mol} \%)$ a series of five reversible redox couples is observed at fast scan rates $\left(2 \mathrm{~V} \mathrm{~s}^{-1}\right)$, labelled a1/c1 to a5/c5 (Figure $3 \mathrm{~A})$. The a1/c1 couple $\left(E_{\mathrm{mid}}=0.19 \mathrm{~V}, \Delta E_{\mathrm{p}}\right.$ $=0.12)$ is assigned to the six electron reduction of $\mathrm{N}_{2}$ to $\mathrm{N}^{3-}(\mathrm{Eq}$. 1) having the lowest midpoint potential of all the couples, slightly more negative than the reported formal potential $\left(E^{0^{\prime}}=0.382\right.$ V). ${ }^{[28]} A$ similar reduction peak appears when $N_{2}$ is bubbled over 
a $\mathrm{Ni}$ wire in pure $\mathrm{LiCl}-\mathrm{KCl}$ electrolyte (Figure $\mathrm{S} 2$ ), while a slow scan of a $\mathrm{Ni}$ foam electrode in $\mathrm{Li}_{3} \mathrm{~N}(0.5 \mathrm{~mol} \%)$ shows a linear current-potential relationship also with $0.19 \mathrm{~V}$ as the $x$ intercept (Figure S3). Examination of the blank voltammogram reveals a single reduction peak around the position of $c 4$, attributed to the
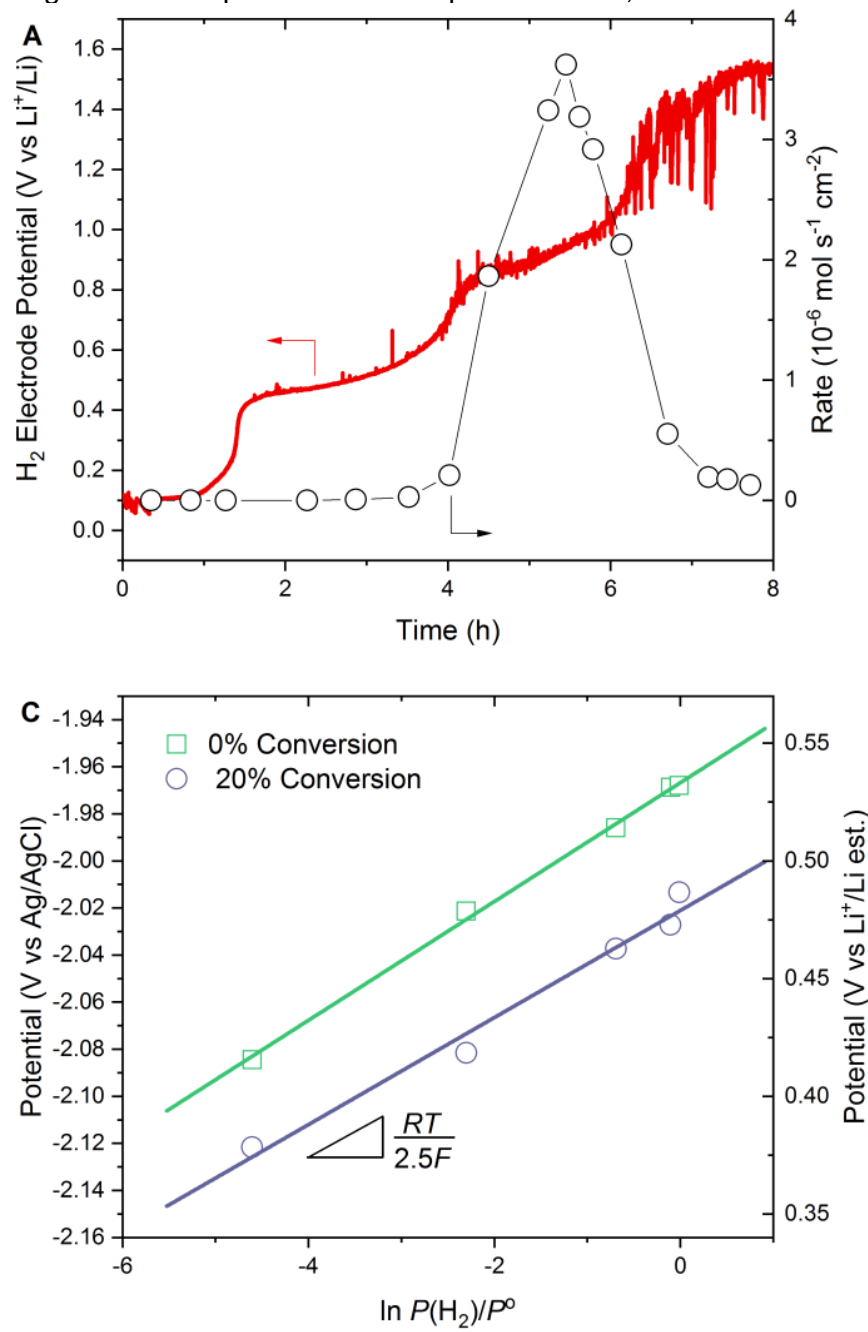

one electron reduction of residual $\mathrm{H}_{2} \mathrm{O}$ to $\mathrm{H}_{2}+\mathrm{OH}^{-}{ }^{[29]}$ The magnitude of this reduction current, along with a suitable estimate of the electrode area, can be used to deduce the amount of water in the melt, which is estimated to be $0.03 \mathrm{~mol} \%$. This non-
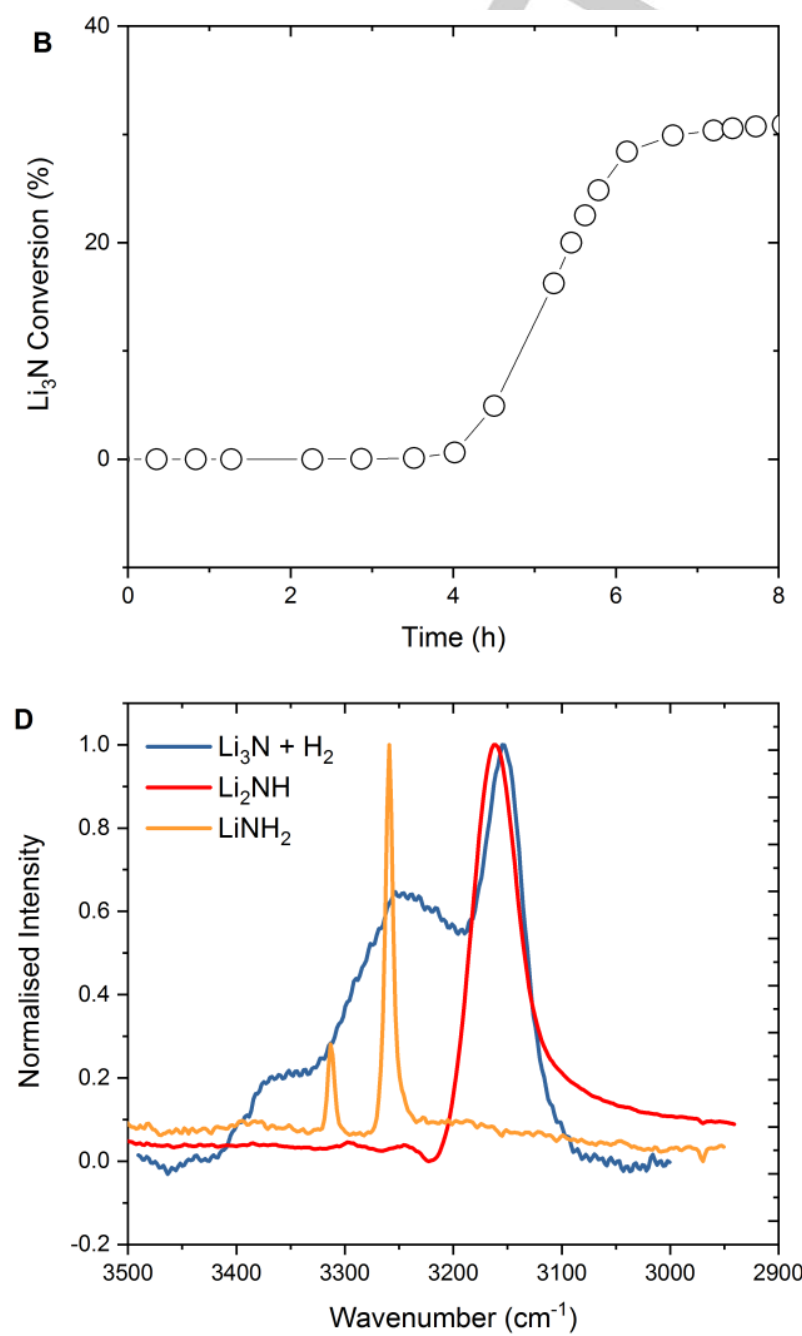

Figure 2. Ammonia evolution at open circuit. Electrolyte: $\mathrm{LiCl}_{-} \mathrm{KCl}-\mathrm{Li}_{3} \mathrm{~N}(0.5 \mathrm{~mol} \%), 723 \mathrm{~K} . \mathrm{Ni}$ felt electrodes. Flow rates: $\mathrm{H}_{2}, 5 \mathrm{~mL}^{\mathrm{min}}{ }^{-1}, \mathrm{~N}_{2}, 10 \mathrm{~mL} \mathrm{~min}^{-1}, \mathrm{Ar}$ (headspace) $250 \mathrm{~mL} \mathrm{~min}{ }^{-1}$. A: Open circuit potential (left) and ammonia evolution rate (right). B: Conversion of initial Li 3 . C: Equilibrium potential dependence of $\mathrm{LiCl}-\mathrm{KCl}-\mathrm{Li}_{3} \mathrm{~N}(0.5 \mathrm{~mol} \%)$ on $\mathrm{H}_{2}$ partial pressure before and after reaction with $\mathrm{H}_{2}$. Measured against $\mathrm{Ag} / \mathrm{AgCl}$ reference electrode. D: Infrared difference spectrum in $\mathrm{N}-\mathrm{H}$ stretching region of frozen $\mathrm{LiCl}-\mathrm{KCl}-\mathrm{Li}_{3} \mathrm{~N}$ after reaction with $\mathrm{H}_{2}$. $\mathrm{Li}_{2} \mathrm{NH}$ and $\mathrm{LiNH}_{2}$ shown for reference.

negligible amount of water may react with some of the $\mathrm{N}^{3-}$ to generate the same protonated species as that formed via reaction with $\mathrm{H}_{2}$ (Eq. 8,9), explaining the presence of further peaks in the voltammetry. To confirm that these species are indeed formed, voltammograms were also collected of $\mathrm{Li}_{2} \mathrm{NH}, \mathrm{LiNH}_{2}$ and $\mathrm{LiH}$.

$$
\begin{aligned}
& \mathrm{N}^{3-}+\mathrm{H}_{2} \mathrm{O}=\mathrm{NH}^{2-}+\mathrm{OH}^{-} \\
& \mathrm{NH}^{2-}+\mathrm{H}_{2} \mathrm{O}=\mathrm{NH}_{2}^{-}+\mathrm{OH}^{-}
\end{aligned}
$$

The voltammogram of $\mathrm{LiNH}_{2}$ at $2 \mathrm{~V} \mathrm{~s}^{-1}$ (Figure $3 \mathrm{C}$ ) consists of four pairs of peaks, aligning well with the a1/c1, a2/c2, a3/c3 and a5/c5 couples seen in $\mathrm{Li}_{3} \mathrm{~N}$. At the slower scan rate of $100 \mathrm{mV} \mathrm{s}^{-1}$ (Figure 3D) only a $1 / \mathrm{c} 1$ is reversible, with c2 appearing much more significant than a2 and the a5/c5 couple replaced by a noisy limiting oxidation current. In comparison, the voltammograms of $\mathrm{Li}_{2} \mathrm{NH}$ only shows a single clear couple (Figure $3 \mathrm{E}$ ), aligning with a2/c2, which also appears to become irreversible at the slower scan rate (Figure $3 \mathrm{~F}$ ). The scan also shows evidence for a high potential shoulder on a2 matching the potential of the a3 peak. The onset of a new oxidation process is also observed at potentials more positive than $1.5 \mathrm{~V}$. The occurrence of the a2/c2 couple in both $\mathrm{NH}^{2-}$ and $\mathrm{NH}_{2}^{-}$is unsurprising, given that even in the absence of $\mathrm{H}_{2}$, when $\mathrm{LiNH}_{2}$ was added to $\mathrm{LiCl}-\mathrm{KCl}$ at $723 \mathrm{~K}$ 
around 25 mol\% was immediately evolved as $\mathrm{NH}_{3}$ (data not shown), presumably via the reaction shown in Eq. 5, suggesting a corresponding $25 \mathrm{~mol} \%$ is converted into $\mathrm{NH}^{2-}$. This suggests that measurements of $\mathrm{LiNH}_{2}$ are actually measurements of both $\mathrm{NH}_{2}^{-}$and $\mathrm{NH}^{2-}$, here in the apparent ratio $2: 1$.

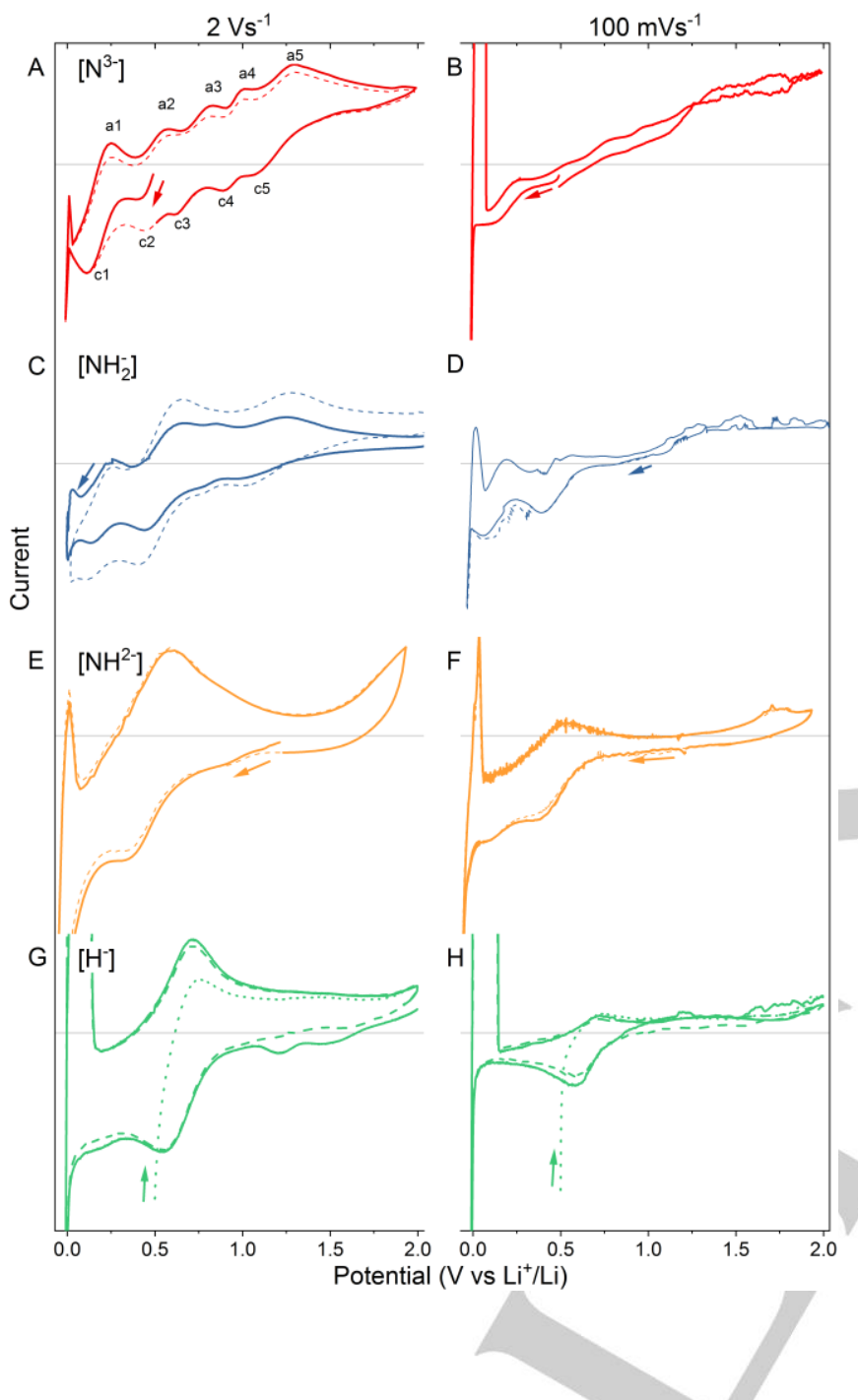

Figure 3. Cyclic voltammetry of the proposed N,H species. First (dotted/solid lines) and second (dashed lines) cycles shown. Arrows indicate starting potential and direction of scan. A,B: $\mathrm{Li}_{3} \mathrm{~N}(0.5 \mathrm{~mol} \%) \mathrm{C}$ : $\mathrm{LiNH}_{2}(0.2 \mathrm{~mol} \%), \mathrm{D}$ : $\mathrm{LiNH}_{2}(1.2 \mathrm{~mol} \%), \mathrm{E}, \mathrm{F}: \mathrm{Li}_{2} \mathrm{NH}$ (1 mol\%), G,H: LiH (1 mol\%). A, C, E, G: scan rate: $v=2 \mathrm{~V} \mathrm{~s}^{-1}, \mathrm{~B}, \mathrm{D}, \mathrm{F}, \mathrm{H}: \mathrm{v}=100 \mathrm{mV} \mathrm{s}^{-1}$

Focusing on the assignment of the a2/c2 couple $\left(E_{\text {mid }}=0.51 \mathrm{~V}\right.$, $\Delta E_{\mathrm{p}}=0.12$ ), there are limited options for reactions of $\mathrm{NH}^{2-}$ which could explain the irreversible reduction behaviour seen at slow scan rates in Figure 3D. One possible reduction would form $\mathrm{N}^{3-}$ and $\mathrm{H}^{-}$(Eq. 10), however, based on the earlier assignment of the $\mathrm{N}_{2} / \mathrm{N}^{3-}$ couple, $\mathrm{N}^{3-}$ would not stable above $0.19 \mathrm{~V}$ and a net oxidation would be observed instead.

$\mathrm{NH}^{2-}+2 \mathrm{e}=\mathrm{N}^{3-}+\mathrm{H}^{-}$

(10)
It is therefore suggested that $\mathrm{NH}^{2-}$ is specifically adsorbed at high potential during the scan, such that current observed at a2/c2 arises from reductive desorption (Eq. 11). This can be followed by decomposition to form $\mathrm{N}(\mathrm{ad})$ and $\mathrm{H}(\mathrm{ad})$ (Eq. 12), which themselves can be reduced (Eq. 13-14), presumably at the same potentials as $\mathrm{c} 1$ and $\mathrm{c} 3$, respectively. The production of $\mathrm{H}$ from $\mathrm{NH}^{2-}$ during a2/c2 explains why the current for the non- $\mathrm{N}$ based a3/c 3 couple is of similar magnitude to the $\mathrm{N}$ based processes.

$\mathrm{NH}(\mathrm{ad})+2 \mathrm{e}=\mathrm{NH}^{2}$

$\mathrm{NH}(\mathrm{ad})=\mathrm{N}(\mathrm{ad})+\mathrm{H}(\mathrm{ad})$

$\mathrm{N}(\mathrm{ad})+3 e=\mathrm{N}^{3-}$

$\mathrm{H}(\mathrm{ad})+\mathrm{e}=\mathrm{H}^{-}$

Reduction of $\mathrm{N}(\mathrm{ad})$ is evident in the slower scan rate scans in both $\mathrm{NH}^{2-}$ and $\mathrm{NH}_{2}^{-}$as a second reduction peak at the $\mathrm{c} 1$ position (Figure 3D,F). The much greater significance of the a1/c1 peaks in both $\mathrm{NH}_{2}{ }^{-}$scans is tentatively attributed to the more facile loss of $\mathrm{H}_{2}$ from $\mathrm{NH}_{2}{ }^{-}$than $\mathrm{NH}^{2-}$, resulting in a lower coverage of $\mathrm{H}(\mathrm{ad})$ and thereby favouring reductive desorption of $\mathrm{N}(\mathrm{ad})$ as $\mathrm{N}^{3-}$ over reaction with $\mathrm{H}(\mathrm{ad})$ and desorption as $\mathrm{NH}^{2-}$.

Following the same approach, the a5/c5 couple $\left(E_{\text {mid }}=1.19 \mathrm{~V}\right.$, $\Delta E_{\mathrm{p}}=0.20$ ) can be assigned to the adsorption/desorption of the $\mathrm{NH}_{2}{ }^{-}$ion (Eq. 15), with similar decomposition into $\mathrm{N}(\mathrm{ad})$ and $\mathrm{H}(\mathrm{ad})$ possible (Eq. 16).

$\mathrm{NH}_{2}(\mathrm{ad})+\mathrm{e}=\mathrm{NH}_{2}$

$\mathrm{NH}_{2}(\mathrm{ad})=\mathrm{N}(\mathrm{ad})+2 \mathrm{H}(\mathrm{ad})$

The difference in $\mathrm{N}: \mathrm{H}$ stoichiometry can also be used to explain the different behaviour seen at high potential. While two $\mathrm{NH}(\mathrm{ad})$ molecules must decompose (in adjacent sites) in order to evolve $\mathrm{H}_{2}$, giving the rate equation a quadratic dependence on $\mathrm{NH}^{2-}$ concentration, and the requirement for neighbouring free surface sites, only one $\mathrm{NH}_{2}{ }^{-}$has to decompose to release $\mathrm{H}_{2}$, possibly without requiring adjacent vacant sites, making the process much faster. Thus, for the same concentration, oxidation to $\mathrm{H}_{2}$ is likely to be much faster for $\mathrm{NH}_{2}{ }^{-}$than for $\mathrm{NH}^{2-}$. This matches well with the presence of a noisy, limiting current for $\mathrm{NH}_{2}{ }^{-}$oxidation but only a high potential current peak for $\mathrm{NH}^{2-}$ oxidation.

Finally, the a3/c3 couple ( $E_{\text {mid }}=0.73 \mathrm{~V}, \Delta E_{\mathrm{p}}=0.20$ ) is readily assigned to the $\mathrm{H}_{2} / \mathrm{H}^{-}$couple (Equation 6), based on the voltammetry of $\mathrm{LiH}$ (Figure $3 \mathrm{G}, \mathrm{H}$ ) and the previously reported midpoint potential $(0.755 \mathrm{~V}$ at $673 \mathrm{~K}) .^{[30]}$ Interestingly at slow scan rates (Figure $3 \mathrm{H}$ ) $\mathrm{H}^{-}$also exhibits a noisy limiting oxidation current, similar to $\mathrm{NH}_{2}{ }^{-}$, further supporting the assignment of the limiting current to $\mathrm{H}_{2}$ evolution. 


\section{Ammonia Synthesis from LiH}

From our analysis of the original $\mathrm{LiCl}-\mathrm{KCl}-\mathrm{Li}_{3} \mathrm{~N}$ system we conclude that the addition of $\mathrm{Li}_{3} \mathrm{~N}$ provides a non-catalytic route to ammonia evolution, casting doubt about the feasibility of the original cell. However, our analysis also suggests that a true, alternative pathway to catalytic ammonia production does exist. If the cell can be made to reduce $\mathrm{N}_{2}$ to $\mathrm{N}^{3-}$, then this should spontaneously react with $\mathrm{H}_{2}$ gas to form ammonia and $\mathrm{H}^{-}$ions. The catalytic cycle could then be closed by oxidizing the $\mathrm{H}^{-}$at the anode. The desired cell reaction would then be represented by Eq. 1, Eq. 4 and Eq. 6, and is shown schematically in Figure 4. Note that it might appear more obvious to couple oxidation of $\mathrm{H}_{2}(\mathrm{~g})$ than $\mathrm{H}^{-}(\mathrm{sol})$ in this reaction, however its standard potential in $\mathrm{LiCl}-\mathrm{KCl}$ is highly positive $\left(E^{0^{\prime}}\left(\mathrm{H}_{2} / \mathrm{H}^{+}\right)_{\text {calc }}=+2.610 \mathrm{~V}\right.$ vs $\left.\mathrm{Li}^{+} / \mathrm{Li}\right),{ }^{[31,32]}$ almost the same as the Ni electrode itself $\left(E^{\prime}=+2.615\right.$ $\mathrm{V})$, ${ }^{[32]}$ leading to much higher electrolysis voltages and the risk of corroding the electrode (see S4, Supporting Information).

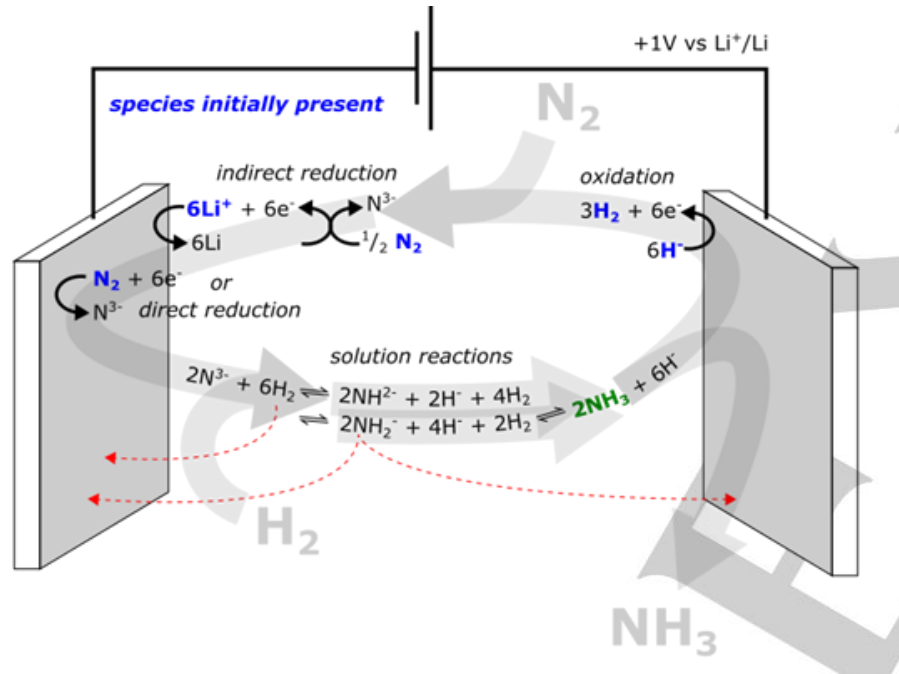

Figure 4. Catalytic cycle proposed for electrochemical $\mathrm{NH}_{3}$ synthesis in molten $\mathrm{LiCl}-\mathrm{KCl}-\mathrm{LiH}$. Species added to the reaction are shown in blue, remaining species in black are generated in situ, sole product $\mathrm{NH}_{3}$ is shown in green. Red dashed lines indicate opportunities for unproductive side reactions.

We therefore setup the $\mathrm{LiH}$ cell to confirm catalytic ammonia production is feasible. The operating conditions were modified slightly $\left(1 \mathrm{~mol} \% \mathrm{LiH}\right.$ in place of $0.5 \mathrm{~mol} \% \mathrm{Li}_{3} \mathrm{~N}, 1.0 \mathrm{~V}$ anode potential, same gas electrodes and flow rates) and the cell tested for $\mathrm{NH}_{3}$ synthesis activity over the course of 3 hours (Figure 5, S2 Supporting Information). Note that $1.0 \mathrm{~V}$ was chosen to favour productive $\mathrm{H}^{-}$oxidation over unproductive reaction of $\mathrm{NH}_{2}^{-}$, based on the voltammetry (Figure 3 ), and $\mathrm{LiH}$ was added from beginning to facilitate $\mathrm{H}^{-}$oxidation before the homogeneous melt reactions (Eq. $4 \mathrm{a}-\mathrm{c}$ ) reached steady state.

Initially very large current densities were observed, but these decreased over the course of one hour. Similar to the $\mathrm{N}^{3-}$ case, $\mathrm{NH}_{3}$ evolution is not observed until after the current has decreased (Figure 5 and Section S3, SI), presumably along with the $\mathrm{H}^{-}$ion concentration, suggesting that $\mathrm{H}^{-}$may also trap $\mathrm{NH}_{3}$ via the reverse reaction of Eq. 4c. The rate of $\mathrm{NH}_{3}$ evolution peaks at $2.8 \times 10^{-8} \mathrm{~mol} \mathrm{~cm}^{-2} \mathrm{~s}^{-1}$ after 2.2 hours online, which is among the highest reported rate for any electrochemical ammonia synthesis. The overall current efficiency, based on the total charge passed and the total ammonia produced, was $4.2 \%$, while the average molar conversion of $\mathrm{N}_{2}$ was $0.011 \mathrm{~mol} \%$. This can be compared to the maximum conversion of $0.006 \mathrm{~mol} \%$ expected for purely thermal equilibrium of the gas mixture over the course of the experiment (calculations in Supporting Information, Table S4, and Figure S4).

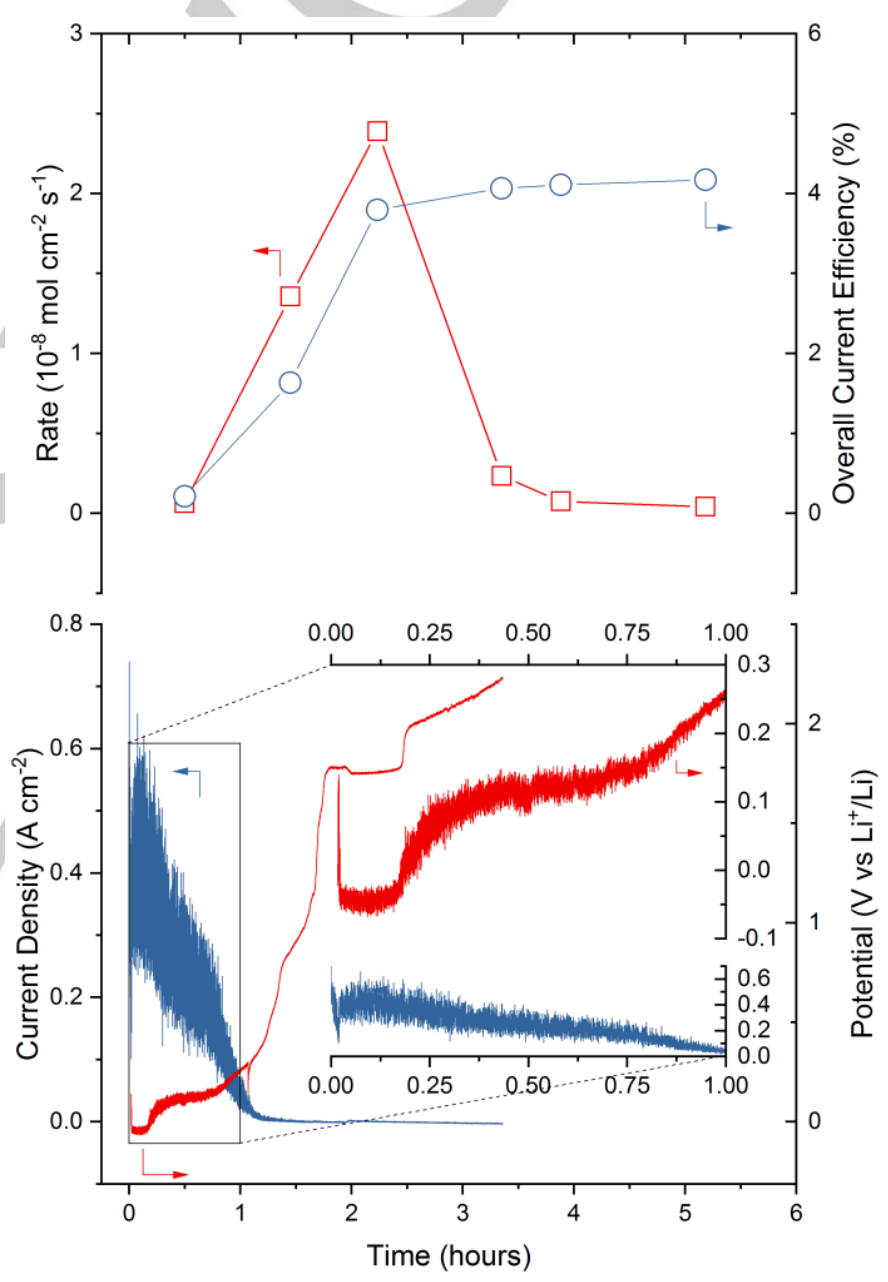

Figure 5. $\mathrm{NH}_{3}$ synthesis results based on $\mathrm{N}_{2}$ reduction in a $\mathrm{LiCl}-\mathrm{KCl}$-LiH (1 mol\%) electrolyte. $T=723 \mathrm{~K}$, Flow rates: $\mathrm{H}_{2}=5 \mathrm{~mL} \mathrm{~min}^{-1}, \mathrm{~N}_{2}=45 \mathrm{~mL} \mathrm{~min}^{-1}, \mathrm{Ar}$ headspace purge $=350 \mathrm{~mL} \mathrm{\textrm {min } ^ { - 1 }}$. Geometric electrode area $=0.126 \mathrm{~cm}^{2} . \mathrm{H}_{2}$ electrode potential $=+1.0 \mathrm{~V}$ vs $\mathrm{Li}^{+} / \mathrm{Li}$.

To confirm that $\mathrm{NH}_{3}$ evolved is a result of $\mathrm{N}_{2}$ reduction in our system rather than from an extraneous source, an isotope labelling experiment was performed (Figure 6). All conditions were maintained as in the previous $\mathrm{LiH}$ experiment, with the exception of the $\mathrm{N}_{2}$ source, which was replaced with ${ }^{15} \mathrm{~N}_{2}$ for 
approximately 1 hour (the contents of one cylinder), after which the source was switched back to ${ }^{14} \mathrm{~N}_{2}$ for the remaining time. Very similar current densities are observed in the ${ }^{15} \mathrm{~N}_{2}$ experiment (Figure 6A), along with a similar (but slightly extended) delay in $\mathrm{NH}_{3}$ evolution. ${ }^{1} \mathrm{H}$ NMR spectroscopy was used to distinguish between the isotopes of $\mathrm{NH}_{3}$ present in the trap solution, based on the different coupling between ${ }^{1} \mathrm{H}$ and ${ }^{15} \mathrm{~N}(I=1 / 2)$ and ${ }^{14} \mathrm{~N}(I=$ 1) as previously described. ${ }^{[33]}$ The NMR spectra (Figure 6B) show only the characteristic triplet of ${ }^{14} \mathrm{NH}_{3}$ in the first three time points, followed by the sudden appearance of a doublet attributed to ${ }^{15} \mathrm{NH}_{3}$, corresponding with the peak in the rate. The presence of ${ }^{15} \mathrm{NH}_{3}$ confirms that $\mathrm{N}_{2}$ is being reduced in the reactor and thus this represents the first demonstration of truly catalytic ammonia synthesis in $\mathrm{LiCl}-\mathrm{KCl}$ eutectic, i.e. without starting from $\mathrm{Li}_{3} \mathrm{~N}$ in the melt, as in previous studies. ${ }^{[10,17,21]}$
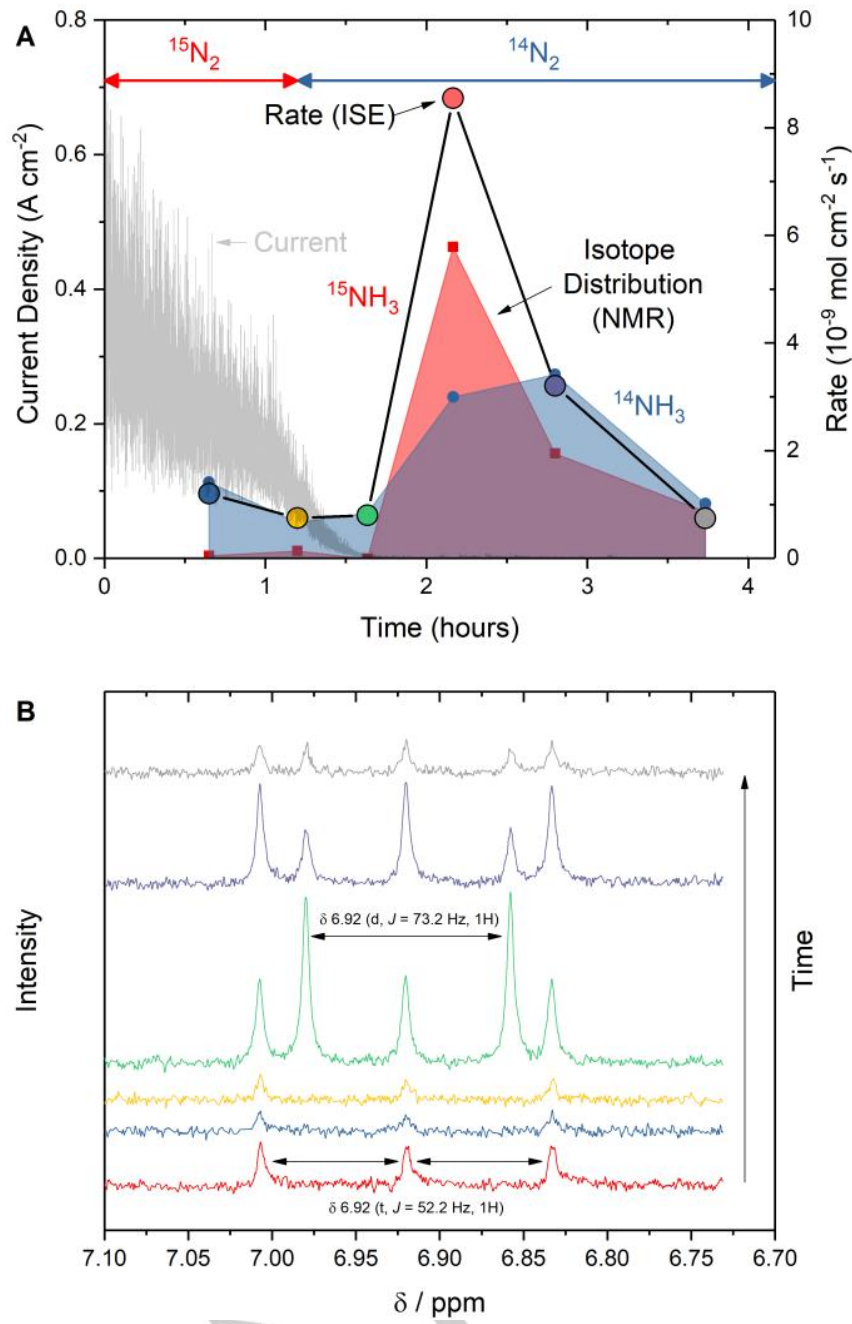

Figure 6 Isotope labelling study to confirm presence of $\mathrm{N}_{2}$ reduction. Reaction conditions as in Figure 6, except ${ }^{15} \mathrm{~N}_{2}$ was used for the first hour. A: Current (black line) $\mathrm{NH}_{3}$ production rate determined by ISE (coloured points) and distribution of ${ }^{15} \mathrm{NH}_{3}$ and ${ }^{14} \mathrm{NH}_{3}$ produced at different times during reaction (based on the absolute values found by integrating the respective multiplet, shown in panel B, below). B: ${ }^{1} \mathrm{H}$ NMR spectra of the trap solutions. Spectra shown offset for clarity.
Performing the isotope experiment in this way not only provides confirmation that $\mathrm{N}_{2}$ is being reduced in our system, but enables the origin of the decay in current and rate over time to be examined via the evolution of the ${ }^{15} \mathrm{NH}_{3} /{ }^{14} \mathrm{NH}_{3}$ product distribution. The presence of ${ }^{14} \mathrm{NH}_{3}$ at early times presumably corresponds to reduction of residual ${ }^{14} \mathrm{~N}_{2}$ in the reactor or gas tubing (despite evacuating and refilling the system with $\mathrm{Ar}$ multiple times). Furthermore, usually the system is purged with $\mathrm{N}_{2}$ before an experiment, allowing the melt to equilibrate before applying the voltage, however to conserve ${ }^{15} \mathrm{~N}_{2}$, Ar was used to purge and the gas flow was only switched to ${ }^{15} \mathrm{~N}_{2}$ just before applying the voltage. This difference may explain the slight delay in the peak rate appearing.

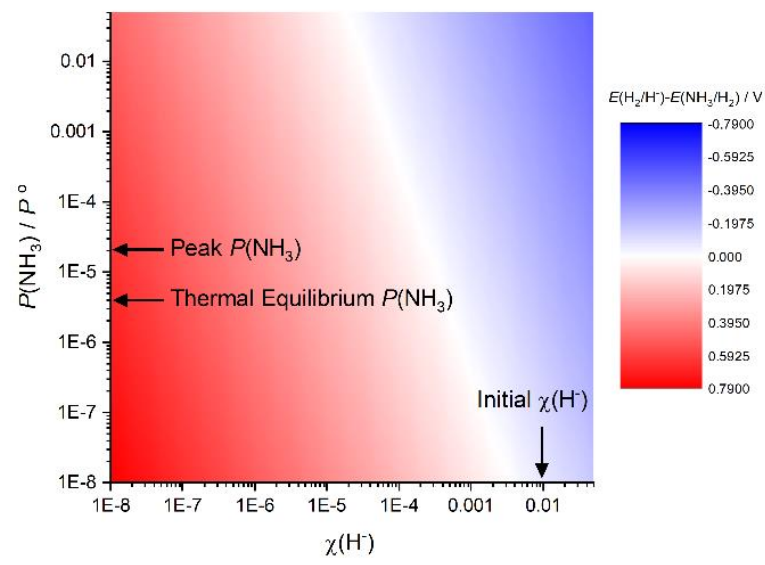

Figure 7 Reaction conditions where the hydrogenation of $\mathrm{N}^{3-}$ is spontaneous (red) or non-spontaneous (blue). Defined as red region where $E\left(\mathrm{H}_{2} / \mathrm{H}^{-}\right)$$E\left(\mathrm{NH}_{3} / \mathrm{H}_{2}\right)>0 . T=723 \mathrm{~K}, X\left(\mathrm{~N}^{3-}\right)=10^{-4}, P\left(\mathrm{H}_{2}\right) / P^{\circ}=0.0125$.

The significant (1900 s) delay between ${ }^{15} \mathrm{~N}_{2}$ flow ending and the evolution of ${ }^{15} \mathrm{NH}_{3}$ provides an estimate of the time taken for the nascent $\mathrm{N}^{3-}$ to react with $3 \mathrm{H}_{2}$ to form $\mathrm{NH}_{3}$ and leave the melt. Interestingly, there is no corresponding sharp peak for ${ }^{14} \mathrm{NH}_{3}$. This indicates that exchange of $\mathrm{H}$ between $\mathrm{NH}^{2-}$ and $\mathrm{NH}_{2}{ }^{-}$is faster than the reaction between $\mathrm{NH}_{2}{ }^{-}$and $\mathrm{H}_{2}$, such that while it takes a long time for successive reactions of ${ }^{15} \mathrm{~N}^{3-}$ to generate ${ }^{15} \mathrm{NH}_{3}$, later when ${ }^{14} \mathrm{~N}^{3-}$ forms it can rapidly equilibrate with the existing ${ }^{15} \mathrm{NH}_{2}$ and ${ }^{15} \mathrm{NH}^{2-}$ species, permitting ${ }^{14} \mathrm{NH}_{3}$ evolution almost immediately after switching gases.

It is clear from the behaviour of the current that the cell reactions has not yet reached the steady state as summarised in Figure 4. The reason for this becomes clear when the conditions required for the spontaneous solution reactions $(4 a)-(4 c)$ to occur are considered. The $\mathrm{H}$ disproportionation reactions proposed to occur in the electrolyte can be separated into two half reactions:

$2 \mathrm{~N}^{3-}+3 \mathrm{H}_{2} \rightarrow 2 \mathrm{NH}_{3}+6 \mathrm{e}^{-}$ 
$3 \mathrm{H}_{2}+6 \mathrm{e}^{-} \rightarrow 6 \mathrm{H}^{-}(6)$

To be spontaneous the potential of the disproportionation reaction must be positive, i.e. $E\left(\mathrm{H}_{2} / \mathrm{H}^{-}\right)-E\left(\mathrm{NH}_{3} / \mathrm{H}_{2}\right)>0$. This difference is calculated over a range of $P\left(\mathrm{NH}_{3}\right)$ and $\mathrm{x}\left(\mathrm{H}^{-}\right)$values in Figure 7. It can be seen that the $\mathrm{H}^{-}$concentration must decrease from $1 \mathrm{~mol} \%$ before spontaneous reaction to form $\mathrm{NH}_{3}$ becomes possible, explaining the delay in $\mathrm{NH}_{3}$ evolution observed. Should $P\left(\mathrm{NH}_{3}\right)$ or $\mathrm{X}\left(\mathrm{H}^{-}\right)$then rise significantly during operation the melt reactions become unfavourable and $\mathrm{NH}_{3}$ evolution stops. To operate at steady state the cell must therefore be operated under closely controlled conditions. It appears from experiments in Figure 5 and 6 that conditions to achieve this steady state have not yet been found, explaining the drop in $\mathrm{NH}_{3}$ production over time. In addition, corrosion or passivation of the $\mathrm{Ni}$ foam electrodes could affect the rate. Both electrodes appear black after the reaction (Figure S5), although there is no sign of $\mathrm{NiO}$ in the $\mathrm{X}$-ray diffraction patterns of pulverised electrodes (Figure $\mathrm{S} 6$ ), just soluble $\mathrm{NiCl}_{2}$. The next step in the development of this cell is therefore the optimisation of the reaction conditions to maximise production of $\mathrm{NH}_{3}$ while maintaining low concentrations of $\mathrm{NH}_{3}$ to remain in the spontaneous regime. One way to achieve this may be by the introduction of porous membranes to separate the electrolyte at the anode, from the bulk and from that at the cathode, minimising crossover, as suggested recently. ${ }^{[34]}$

\section{Conclusion}

From this work, we have shown that the previous assumption of direct electrochemical reaction of $\mathrm{N}_{2}$ and $\mathrm{H}_{2}$ in molten $\mathrm{LiCl}-\mathrm{KCl}$ to form $\mathrm{NH}_{3}$ with high efficiency is not correct. Detailed investigation into the electrochemical mechanism has revealed the existence of a number of rapid non-electrochemical reactions of $\mathrm{N}^{3-}$ with $\mathrm{H}_{2}$ to form $\mathrm{NH}_{3}$ along with $\mathrm{NH}^{2-}$ and $\mathrm{NH}_{2}^{-}$, which are shown to be electrochemically active by cyclic voltammetry. This insight led us to propose a new, truly catalytic reaction scheme. Based on this we demonstrate electrochemical $\mathrm{NH}_{3}$ synthesis from $\mathrm{N}_{2}$ and $\mathrm{H}_{2}$ at some of the highest rates yet reported, and confirm this by ${ }^{15} \mathrm{~N}_{2}$ labelling. The understanding provided by this work should enable more extensive optimisation of this cell and realisation of longer term sustained electrochemical ammonia synthesis.

\section{Experimental Section}

Electrochemical experiments were carried out in a stainless steel cell mounted inside an electric furnace (Figure S1). An alumina crucible suspended from the top of the cell held the $\mathrm{LiCl} / \mathrm{KCl}$ mixture $(59: 41 \mathrm{~mol} \%$, 99\% Alfa Aesar), which was extensively dried before use. Gas electrodes were formed of rolled $\mathrm{Ni}$ foam inserted into alumina tubes, with $\mathrm{Ni}$ wire connections. The reference electrode was $\mathrm{Ag} / \mathrm{AgCl}$, prepared by adding $\mathrm{AgCl}(99.9 \%$, Alfa Aesar) to LiCl-KCl $(0.05 \mathrm{~mol} \%)$ in a Pyrex tube with one end closed, and contacting the salt with a Ag wire (99.9\%, Alfa Aesar). A new electrode was used for each measurement. All potentials are converted into the $\mathrm{Li}^{+} / \mathrm{Li}$ scale by correlation with the potential of zero current in cyclic voltammograms of a Ni wire after sweeping to $\mathrm{Li}^{+}$reduction potentials. The cell was operated under potentiostatic control using either a Vertex or CompactStat potentiostat (Ivium Technologies) at $723 \mathrm{~K}$. Mass flow controllers supplied $\mathrm{N}_{2}(99.998 \%, \mathrm{BOC})$ and $\mathrm{H}_{2}(99.99 \%, \mathrm{BOC})$ to the respective electrodes, while the cell headspace was purged with $\mathrm{Ar}$ (99.998\%, BOC). Outlet gas passed was through an acid trap containing dilute $\mathrm{H}_{2} \mathrm{SO}_{4}(0.01 \mathrm{M}, 50 \mathrm{~mL})$. The acid trap was changed periodically and analysed with an ion selective electrode (ThermoFisher Scientific) to determine the rate of ammonia evolution. Use of ${ }^{15} \mathrm{~N}_{2}(98 \%+, \mathrm{CK}$ Isotopes Ltd.) was used to confirm $\mathrm{N}_{2}$ reduction via the presence of ${ }^{15} \mathrm{NH}_{3}$ in the acid trap, as detected by ${ }^{1} \mathrm{H}$ NMR spectroscopy. Further experimental details can be found in supporting information (Tables S1-S4).

\section{Acknowledgements}

This work was funded by Siemens PLC. TS acknowledges an EPSRC CASE studentship and support from a Royal Commission for the Exhibition of 1851 fellowship. N. Vranješ, A. Garzon Gonzalez, T. Adams, L. Hill and S. Davies (University of Oxford) and R. Selway (Inspired Engineering Design Ltd.) are thanked for the design and construction of equipment.

Keywords: Heterogeneous catalysis • electrochemistry • renewable resources; ammonia; nitrogen

[1] P. M. Vitousek, J. D. Aber, R. W. Howarth, G. E. Likens, P. A. Matson D. W. Schindler, W. H. Schlesinger, D. G. Tilman, Ecological Applications 1997, 7, 737-750.

[2] International Energy Agency, Tracking Industrial Energy Efficiency and CO2 Emissions, International Energy Agency, 2007.

[3] International Energy Agency, Ed. , World Energy Outlook 2007, OECD, Paris, 2007

[4] T. Brown, AMMONIA INDUSTRY 2016.

[5] M. Appl, Ammonia : Principles and Industrial Practice, Wiley- $\mathrm{VCH}$ Weinheim ; Chichester, 1999.

[6] E. Morgan, J. Manwell, J. McGowan, Renewable Energy 2014, 72, $51-61$.

[7] I. J. McPherson, T. Sudmeier, J. Fellowes, S. C. E. Tsang, Dalton Trans. 2019, 48, 1562-1568.

[8] S. Giddey, S. P. S. Badwal, A. Kulkarni, International Journal of Hydrogen Energy 2013, 38, 14576-14594.

[9] V. Kyriakou, I. Garagounis, E. Vasileiou, A. Vourros, M. Stoukides, Catalysis Today 2017, 286, 2-13

[10] T. Murakami, T. Nishikiori, T. Nohira, Y. Ito, J. Am. Chem. Soc. 2003, 125, 334-335.

[11] S. Licht, B. Cui, B. Wang, F.-F. Li, J. Lau, S. Liu, Science 2014, 345 637-640.

[12] J. M. McEnaney, A. R. Singh, J. A. Schwalbe, J. Kibsgaard, J. C. Lin, M. Cargnello, T. F. Jaramillo, J. K. Nørskov, Energy Environ. Sci. 2017, 10, 1621-1630.

[13] A. Bonomi, M. Hadate, C. Gentaz, J. Electrochem. Soc. 1977, 124, 982-986.

[14] A. Bonomi, M. Hadate, F. Breda, J. Electrochem. Soc. 1979, 126 248-251.

[15] T. Goto, M. Tada, Y. Ito, J. Electrochem. Soc. 1997, 144, 2271-2276.

[16] Y. Ito, T. Goto, Journal of Nuclear Materials 2005, 344, 128-135.

[17] T. Murakami, T. Nohira, T. Goto, Y. H. Ogata, Y. Ito, Electrochimica Acta 2005, 50, 5423-5426.

[18] T. Murakami, T. Nohira, Y. Araki, T. Goto, R. Hagiwara, Y. H. Ogata, Electrochem. Solid-State Lett. 2007, 10, E4-E6.

[19] T. Murakami, T. Nohira, Y. H. Ogata, Y. Ito, Electrochem. Solid-State Lett. 2005, 8, D12-D14.

[20] T. Murakami, T. Nohira, Y. H. Ogata, Y. Ito, J. Electrochem. Soc. 2005, 152, D109-D112.

[21] T. Murakami, T. Nishikiori, T. Nohira, Y. Ito, J. Electrochem. Soc. 2005, 152, D75-D78.

[22] N. Serizawa, H. Miyashiro, K. Takei, T. Ikezumi, T. Nishikiori, Y. Ito, J. Electrochem. Soc. 2012, 159, E87-E91.

[23] Note that without the involvement of the electrode, the normalisation used is irrelevant and the units of the spontaneous rate should therefore be considered arbitrary 
[24] C. W. Bale, E. Belise, P. Chartrand, S. A. Decterov, G. Eriksson, A. E. Gheribi, K. Hack, I. H. Jung, Y. B. Kang, J. Melancon, et al., Calphad n.d., 54, 35-53.

[25] P. Chen, Z. Xiong, J. Luo, J. Lin, K. L. Tan, Nature 2002, 420, 302304 .

[26] Y. Kojima, Y. Kawai, Journal of Alloys and Compounds 2005, 395, 236-239.

[27] N. Serizawa, K. Takei, T. Nishikiori, Y. Katayama, Y. Ito, Electrochemistry 2018, 86, 88-91.

[28] T. Goto, Y. Ito, Electrochimica Acta 1998, 43, 3379-3384.

[29] S. H. White, in Ionic Liquids, Plenum Press, New York, 1981, p. 450

[30] T. Nohira, Y. Ito, J. Electrochem. Soc. 2002, 149, E159-E165.

[31] H. A. Laitinen, J. A. Plambeck, J. Am. Chem. Soc. 1965, 87, 12021206.

[32] H. C. Gaur, H. L. Jindal, Electrochimica Acta 1968, 13, 835-842.

[33] F. Zhou, L. Miguel Azofra, M. Ali, M. Kar, A. N. Simonov, C McDonnell-Worth, C. Sun, X. Zhang, D. R. MacFarlane, Energy \& Environmental Science 2017, 10, 2516-2520.

[34] Y. Ito, T. Nishikiori, H. Tsujimura, Faraday Discuss. 2016, 190, 307326. 
Entry for the Table of Contents (Please choose one layout)

Layout 1:

\section{RESEARCH ARTICLE}

This work

identifies the key

challenges and

opporutnities of

using molten

$\mathrm{LiCl}$ eutectics as

media for the

direct

electrochemical

reduction of $\mathrm{N}_{2}$

to ammonia with

high efficiency.

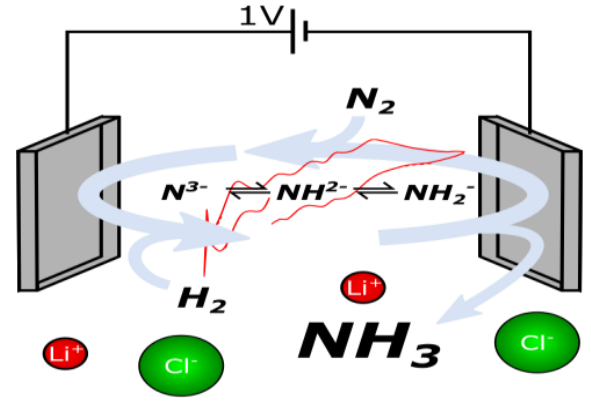

I.J. McPherson, T. Sudmeier, J. P. Fellowes, I. Wilkinson,

T. Hughes and S.C.E. Tsang*

Page No. - Page No.

The Feasibility of Electrochemical Ammonia Synthesis in Molten $\mathrm{LiCl}-\mathrm{KCl}$ Eutectics

Layout 2:

\section{RESEARCH ARTICLE}

((Insert TOC Graphic here))
Author(s), Corresponding Author(s)*

Page No. - Page No.

Title

Text for Table of Contents 